A RAIN OF DARTS

THE MEXICA AZTECS 
THIS PAGE INTENTIONALLY LEFT BLANK 
The Texas Pan American Series 
THIS PAGE INTENTIONALLY LEFT BLANK 


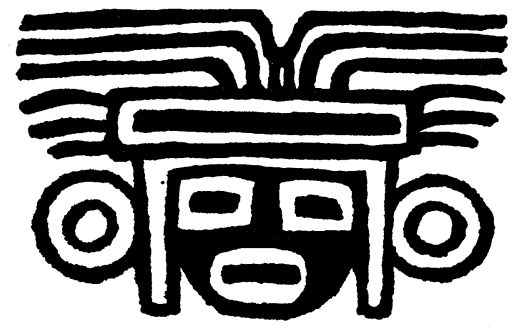

\section{A Rain of Darts}

THE MEXICA AZTECS

by Burr Cartwright Brundage

UNIVERSITY OF TEXAS PRESS, AUSTIN 
The Texas Pan American Series is published with the assistance of a revolving publication fund established by the Pan American Sulphur Company and other friends of Latin America in Texas.

Library of Congress Cataloging in Publication Data

Brundage, Burr Cartwright, 1912-

A rain of darts.

(Texas pan-American series)

Bibliography: $p$.

1. Aztecs-History. I. Title.

F1219.B89 $\quad 970.3 \quad 72-680$

ISBN 0-292-77002-2

Copyright (ㅇ 1972 by Burr Cartwright Brundage

All Rights Reserved

Composition by G\&S Typesetters, Austin

Printing by The University of Texas Printing Division, Austin

Binding by Universal Bookbindery, Inc., San Antonio

ISBN 978-0-292-76237-4 (library e-book)

ISBN 978-0-292-76238-1 (individual e-book) 
TO ARNOLD TOYNBEE in friendship and gratitude 
THIS PAGE INTENTIONALLY LEFT BLANK 